LEvy, E. (1874) Essai sur l'action physiologique et thérapeutique du bromure de lithium. Paris: Thése.

MitcheLL, S. W. (1877) Clinical lecture on nervousness in the male. Medical News, 35, 177-184.

The Psychiatric Hospital

2 Skovagervej

DK-8240 Risskov, Denmark

MOGENS SCHOU

\section{Women and scientific thought}

SIR: Stephen M. Lawrie (Journal, April 1992, 160, 569-570) suggests that, "To my mind our maledominated, scientific, mechanistic view of mental illness needs to include a more feminine, subjective and sensitive aspect". The notion that scientific thought is a male dominion is damning to women. Even more objectionable (if possible) is the belief that being subjective and sensitive is incompatible with being scientific and objective.

At the same time, we agree wholeheartedly with Dr Lawrie that there exist problems in psychiatry in the way research is undertaken as a result of academic and funding policies. It is unfortunate that the solution he proposes is both off the point and derogatory to women.

RACHEL G. KLEIN

Columbia University

College of Physicians and Surgeons

and

New York State Psychiatric Institute

New York, $N Y$

\section{Hypertrichosis in mentally ill women}

SIR: Regarding hypertrichosis in insane females (A Hundred Years Ago, Journal, May 1992, 160, 721) the situation remains much the same today as it was in 1892.

The underlying reason for this is that hirsutism is common, especially in dark-haired women over $\mathbf{3 0}$ years of age. The ideal female is not only excessively thin but also prepubertally hairless: hence Ruskin's horror and incredulity on first facing the reality of pubic hair.

Impressive amounts of time and money are devoted by women to depilation. These activities are carried out in secret because of the perceived unattractiveness of hirsutism.

Small wonder that when women become mentally ill, such activities cease and nature takes its course. I think much of the hypertrichosis seen in insane women will tend to disappear once they are well enough to recommence their self-care routines.

12 Charlotte Rd

Catherine J. Feehan

Edgbaston

Birmingham

B15 2NG

\section{Descriptions of psychiatric conditions in literature}

SIR: Sno et al (Journal, April 1992, 160, 511-518) give several examples of descriptions of the déjà $v u$ experience in prose and poetry, and indicate that psychiatrists should read more widely than the psychiatric literature.

A good piece of descriptive writing can help in the understanding of what sufferers might be experiencing when undergoing experiences that would be interpreted by a psychiatrist as a psychiatric condition, and in literature the psychiatric condition, being only a part of the overall piece, is set in the wider context of the person undergoing it, just as psychiatrists attempt to do, albeit in far less detail, when they set a few symptoms against the background of a full Maudsley-type psychiatric history.

If reading more widely from the general literature might help those with less experience of psychiatry gain a feel for some of the conditions that they wish to treat, may I offer a selection of books that might help in the understanding of the more common psychiatric conditions, which might be purchased by a psychiatric library without excessive cost.

Nikolai Gogol provides an account of the development of an acute psychosis in Diary of a Madman (all the foreign books in this selection can be found in the Penguin Classics series), and Evelyn Waugh describes a bromide-induced psychosis for a man on board ship in The Ordeal of Gilbert Pinfold (Penguin, 1962). Anton Chekhov's Black Monk is a short story about a man with manic-depressive psychosis. The central character of Paul Sayer's Comforts of Madness (Sceptre, 1988) has catatonia. The heroine of Sylvia Plath's The Bell Jar (Faber, 1966) experiences a severe neurotic depression, and the central character of J. Bernlef's Out of Mind (tr. A Dixon, Faber \& Faber, 1988) suffers from a dementing process. Emile Zola graphically presents life for the poor in 19th century Paris, the slide into alcohol abuse, and an account of delirium tremens in his book L'assommoir. Henrik Ibsen's play The Wild Duck deals with how relationships work, the basis for good family dynamics and the strains that lead one member to commit suicide; the suicide of Dido in Vergil's Aeneid Book $I V$ arises from anger at being deserted by her lover Aeneas, and Freud's descrip- 
tion of such internalised anger in his essay Mourning and Melancholia (1925) fits this piece well. Walter, in the book of that name by David Cook (Penguin, 1980), is a boy with mental handicap. Shakespeare's plays contain characters with psychological or psychiatric issues: Macbeth's guilt, Lear's madness. Hamlet's introspection and perhaps depression are some better known examples. Further discussion of madness in the theatre can be found in Davis (1992).

A list such as this can be no more than idiosyncratic, but might provide an introduction to those wishing to explore the field of madness in literature. Other suggestions from readers would be welcomed.

DAvis, D. R. (1992) Scenes of Madness-A Psychiatrist at the Theatre. London: Routledge.

Freud, S. (1925) Mourning and melancholia. In Collected Works, Vol 14, pp. 239-258. London: Hogarth Press.

\section{Gordon Hospital}

ROBERT M. COHEN

Bloomburg Street

London SWIV $2 R H$

\section{'Taking Liberties'}

SIR: I am prompted to write this letter after watching the recent BBC2 documentary, Taking Liberties (7 May, 1992). The programme argued a case for death on psychiatric wards being associated with violent and difficult behaviour and poor quality of care. This association with death may be so, but at best the evidence is tenuous (Shah, 1992).

It was a pity that the programme did not concentrate on the more general issue of the established relationship between violent and difficult behaviour, attempted suicides and suicides on psychiatric wards, and staffing levels, agency nursing staff, staff attitudes, under-involvement of medical staff and overcrowding (James et al, 1990; Shah et al, 1991). Intervention at these levels offers opportunity for primary and secondary prevention, which may ultimately not only reduce behaviour disturbance but improve staff and patient morale and quality of care.

The programme appeared to portray that large Victorian hospitals are the mainstay of treatment. This is no longer the case with the closure of large hospitals and implementation of the communitycare policies. However, it has been shown that levels of violence may be increasing in newer psychiatric units in district general hospitals (James et al, 1990). Thus, we should concentrate on all types of psychiatric units.

JAmes, D. V., Fineberg, N. A., Shah, A. K., et al (1990) An increase in violence on an acute psychiatric ward: a study of associated factors. British Journal of Psychiatry, 156, 846-852.
Sнан, A. K. (1992) Violence, death and associated factors on a mental handicap ward. Journal of Intellectual Deficiency Research (in press).

- JAMES, D. V. \& Fineberg, N. A. (1991) Violence among psychiatric in-patients. Acta Psychiatrica Scandinavica, 84, 304-309.

Section of Epidemiology and General Practice

Institute of Psychiatry

De Crespigny Park

Denmark Hill

London SE5 8AF

\section{Neuroleptic-induced dislocation of the jaw}

SIR: We wish to report a case of neuroleptic-induced orofacial dystonia complicated by dislocation of the jaw, to remind clinicians of this uncommon yet serious occurrence.

Case report. A previously well, unmarried, 21-year-old waiter, of Greek origin, was admitted to hospital with recent onset of bizarre behaviour, elevated mood and formal thought disorder. Over the following four weeks his psychosis was treated with haloperidol to a maximum dose of $30 \mathrm{mg}$ daily and adjunctive use of clonazepam, initially at a dose of $\mathbf{2} \mathrm{mg}$ b.d. Throughout this time he experienced intermittent orofacial dystonia, cogwheel rigidity and festinant gait which responded to benztropine, $2 \mathrm{mg}$ per day. The anticholinergic medication was withdrawn over a period of two weeks and he was discharged on haloperidol, $7.5 \mathrm{mg}$ at night.

He was readmitted a week later with recurrent symptoms associated with medication non-compliance and cannabis abuse. He received haloperidol, $20 \mathrm{mg}$ in divided doses, and clonazepam, $2 \mathrm{mg}$ during the initial 12 hours but became more agitated and disturbed and received haloperidol, $20 \mathrm{mg}$, and clonazepam, $2 \mathrm{mg}$, in the subsequent six-hour period. He developed an orofacial dystonic reaction 18 hours after reintroduction of haloperidol. Benztropine, $2 \mathrm{mg}$ intramuscularly, was administered six-hourly without effect. He was noted to have facial asymmetry, difficulty swallowing, salivary drooling and was unable to close his mouth. A dislocated jaw was suspected clinically and an anterior dislocation of the right temporomandibular joint was confirmed radiologically. There was no evidence to suggest traumatic dislocation. Haloperidol was discontinued and his jaw was successfully relocated under sedation. This was followed by a diminution of his agitation without evidence of orofacial dystonia.

His psychosis gradually responded to thiothixene, a high potency antipsychotic agent from a different pharmacological class, without recurrence of dystonia. A diagnosis of schizophreniform disorder was reached and he was discharged to his family home five weeks later.

Dystonic reactions develop in up to $2.5 \%$ of patients treated with antipsychotic agents within 48 hours of their commencement (Rupniak, 1986). The majority are either self-limiting or resolve with anticholinergic drug administration and are not 